\title{
Impact of Guidance and Counselling Services on Academic Performance of Students in Some Selected Secondary Schools in Sokoto Metropolis
}

\author{
Shehu Ibrahim ${ }^{1}$, Iklima Ibrahim Bandi², Jabir Aliyu Danyaya ${ }^{3}$, Mustapha Sahabi ${ }^{4}$, \\ Ibrahim Abubakar ${ }^{5}$ \\ 1, Shehu Shagari College of Education, Sokoto, Nigeria \\ 2, UsmanuDanfodiyoUniversitySokoto, Nigeria \\ 3, WaziriUmaru Federal Polytechnic, BirninKebbi, Nigeria \\ 4, Shehu Shagari College of Education, Sokoto, Nigeria \\ 5, Government Technical College, Farfaru, Sokoto Nigeria \\ Correspondingauthor: shehuibrahim3030@gmail.com
}

\section{ART I C L E INFO}

\section{Article history:}

Received may 2021

Revised june 2021

Accepted july 2021

\section{Keywords:}

academicperformance, guidanceandcounseling, sokoto,

students

\begin{abstract}
A B S T R A C T
The study aims to evaluating the impact of guidance and counseling services on the academic performance of students in some selected secondary schools in Sokoto metropolis. Causalcomparative (Ex-post facto) research design was adopted for this study. This study involves a total of 200 subjects comprising 5 principals, 25 class teachers, 10 teacher counselors, and 160 students from the five selected schools. Data were collected using the four sets of questionnaires. Data analysis was done using descriptive and inferential statistics. The finding revealed that eighty percent $(80 \%)$ of the students responded that their academic performance was changed after receiving counseling services. Seventy-two percent $(72 \%)$ of the class teachers perceived the level of students' academic performance after counseling as good, while $20 \%$ perceived it very good and $8 \%$ rated it bad. Guidance and counseling services have positively influenced the academic performance of the students and should be strengthened to improve the students' performance in national examinations.
\end{abstract}

\section{Introduction}

The educational system involves a process of transmitting the societal norms and values toward the development of a country (Uwaifo, 2009). Guidance and counseling services are an integral and important aspects of educational services (Zunker, 2002; Uwaifo, 2009). Guidance and counseling services help students acquire knowledge, skills, and experience to eliminate overwhelming ignorance on their career choices, identify opinions, explore alternatives and succeed in life (Egbochukwu, 2008). In Nigeria, as contained in the 
National Policy of Education (2004) the goals of the educational services include facilitating the implementation of the educational policy, promoting the effectiveness of the educational system, and making learning experiences more meaningful for children. The guidance and counseling activities are important in achieving these goals by helping students succeed in their educational pursuits.

Guidance is a program of activities that have provided the solution to the many existing problems in the recent era of complex scientific and technological development (Okobiah and Okorodudu, 2004). Eyo et al. (2010), seen guidance as a program of services to individuals based on their needs and the influence of environmental factors. Counseling is a personal relationship in which one person attempts to help another person toward understanding and solving his educational, vocational, and social problems (Egbochukwu, 2008). According to Ebizie et al. (2016) counseling is a learning process in which individuals learn and understand themselves and their environment and make the right choice of behaviors that will help them develop, grow, progress, ascend, mature, and step up in educational, vocational and social activities. Guidance and Counselling refer to the activities of relevant services and processes of helping individuals in the school or society to achieve their goals in their emotional, moral, social, academic, and vocational developments (Okobiah\&Okorodudu, 2006).

School is an environment with an increasing number of problems and students face many challenges (Davis, 2003). Secondary school students are in the adolescent stage which affects their study habits, academic performance, career choices, and future life. During the adolescence period students exhibit nervousness and lack of confidence emotionally, mentally, and morally (Corey, 2005). Studies showed that social, educational, physical, and economic factors affect students' career choices (Eyo, et al., 2010; Eremie, et al., 2018). It has been reported that poor academic performance of students is due to the lack of right study attitudes and the right orientation from the home and society (Essuman, 2007). Through effective guidance and counseling an individual can explore various unlimited opinions in educational, vocational, and social activities (Eremie, et al., 2018). Guidance and counseling services through teaching, advising, instructing, explaining, and opinion enables students to develop self-esteem and evaluate the societal challenges facing them, abilities and gradually develop their life's goals (UNESCO, 2006; Nguyia, 2010). This study was conducted to determine the impact of guidance and counseling services on the academic performance of students in some selected secondary schools in Sokoto metropolis.

\section{Method}

The causal-comparative (Ex-post facto) research design was adopted for the study. The research design was adopted because the independent variable which is the guidance and counseling program has already been established in the selected schools and hence the research was interested in its influence on the academic performance of the students.

The study was conducted in some selected secondary schools in Sokoto metropolis, Sokoto state. Sokoto is the capital city of Sokoto state which is located in the North-West region in Nigeria. Sokoto metropolis is estimated to have a population of 427,760 people (NPC/FGN, 2007) and by the virtue of its origin, the state comprises mostly Hausa/Fulani and other groups such as Gobirawa, Zabarmawa, Kabawa, Adarawa, Arawa, Yoruba, Ibos, and others (MOI, 2008). The research site was chosen due to the available evidence of poor academic performance among students in the selected schools in national examinations. This had pointed out a lapse in the guidance and counseling services in addressing the various educational, social, personal, psychological, and vocational challenges facing students in the selected schools. 
A total of 200 subjects comprising 5 principals, 25 class teachers, 10 counselors, and 160 students from the five selected secondary schools in Sokoto metropolis were used in this study. The five schools were selected by purposive sampling technique and include Nagarta College, Sokoto Teachers College, Sani Dingyadi Unity Secondary School, Government Day Secondary School, and Nana Girls Day Secondary School. The subjects were selected using a simple random sampling technique from the five selected schools.

The data were collected from the selected respondents after receiving permission from the school authorities. The data collected were processed, coded, and analyzed using descriptive and inferential statistics to facilitate answering the research questions. The descriptive analyses were used in summarizing and organizing the data and described the characteristics of the sample population. Inferential statistics were used in making deductions and generalizations about the whole population.

\section{FindingsandDiscussion}

Findings

Table 1 shows the age distribution of the respondents. The highest percentage of the respondents was aged between $15-19$ years while the respondents in the age range $10-14$ years occupied the least percentage (Table 1). The majority of the respondents are students in SS II who are between the ages $15-19$ years and should be the reason for the higher percentage of the respondents.

Table 1

Age of the Respondents

\begin{tabular}{lll}
\hline Age (Year) & Frequency & Percentage (\%) \\
\hline $10-14$ & 2 & 1 \\
$15-19$ & 120 & 60 \\
$20-24$ & 26 & 13 \\
$25-29$ & 10 & 5 \\
$30-34$ & 12 & 6 \\
$35-39$ & 10 & 5 \\
$40-44$ & 6 & 3 \\
$45-49$ & 8 & 4 \\
$>\mathbf{5 0}$ & 6 & 3 \\
\hline
\end{tabular}

The gender distribution of the respondents is shown in figure 1 . The result showed that most of the respondents (71\%) are male (Figure 1). Three boys' boarding schools, one girls' day school, and one mixed school used in this study could be the reason for the higher percentage of the male respondents. 


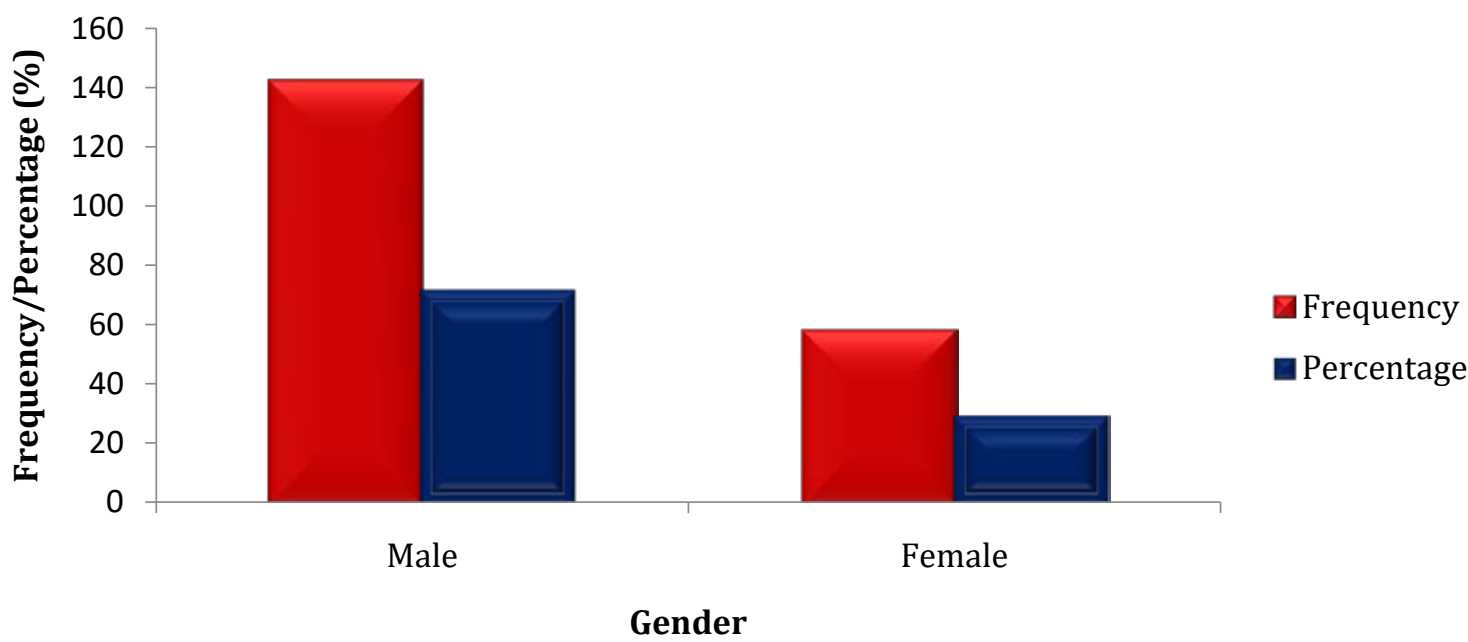

\section{Figure 1}

\section{Gender of the Respondents}

Table 2 shows the educational qualification of the respondents. The majority of the respondents (60\% principal, $80 \%$ counselor, and $60 \%$ class teacher) are first degree holders. Few of the respondents (40\% principal, $10 \%$ counselor, and $8 \%$ class teacher) hold a master's degree. The least qualification is the national diploma (ND) which is held by $4 \%$ of the class teacher (Table 2).

\section{Table 2}

\section{Educational Qualification of the Respondents}

\begin{tabular}{lcllccc}
\hline Qualification & \multicolumn{2}{l}{ Principal } & \multicolumn{2}{c}{ Teacher Counselor } & \multicolumn{2}{c}{ Class Teacher } \\
\cline { 2 - 5 } & Frequency & Percentage & Frequency & Percentage & Frequency & Percentage \\
\hline NCE & - & - & 1 & 10 & 6 & 24 \\
ND & - & - & - & - & 1 & 4 \\
HND & - & - & - & - & 1 & 4 \\
Degree & 3 & 60 & 8 & 80 & 15 & 60 \\
Master & 2 & 40 & 1 & 10 & 2 & 8 \\
\hline
\end{tabular}

Nigeria Certificate in Education (NCE), National Diploma (ND), Higher National Diploma (HND)

\section{Academic Performance of Students}

The distribution for the change in academic performance of the students after counseling services is shown in figure 2 . The result of the study indicated that $80 \%$ of the students responded positively (yes) to the change of their academic performance after counseling while $20 \%$ of the students responded negatively (no) to the change in their academic performance after receiving counseling services (Figure 2). 


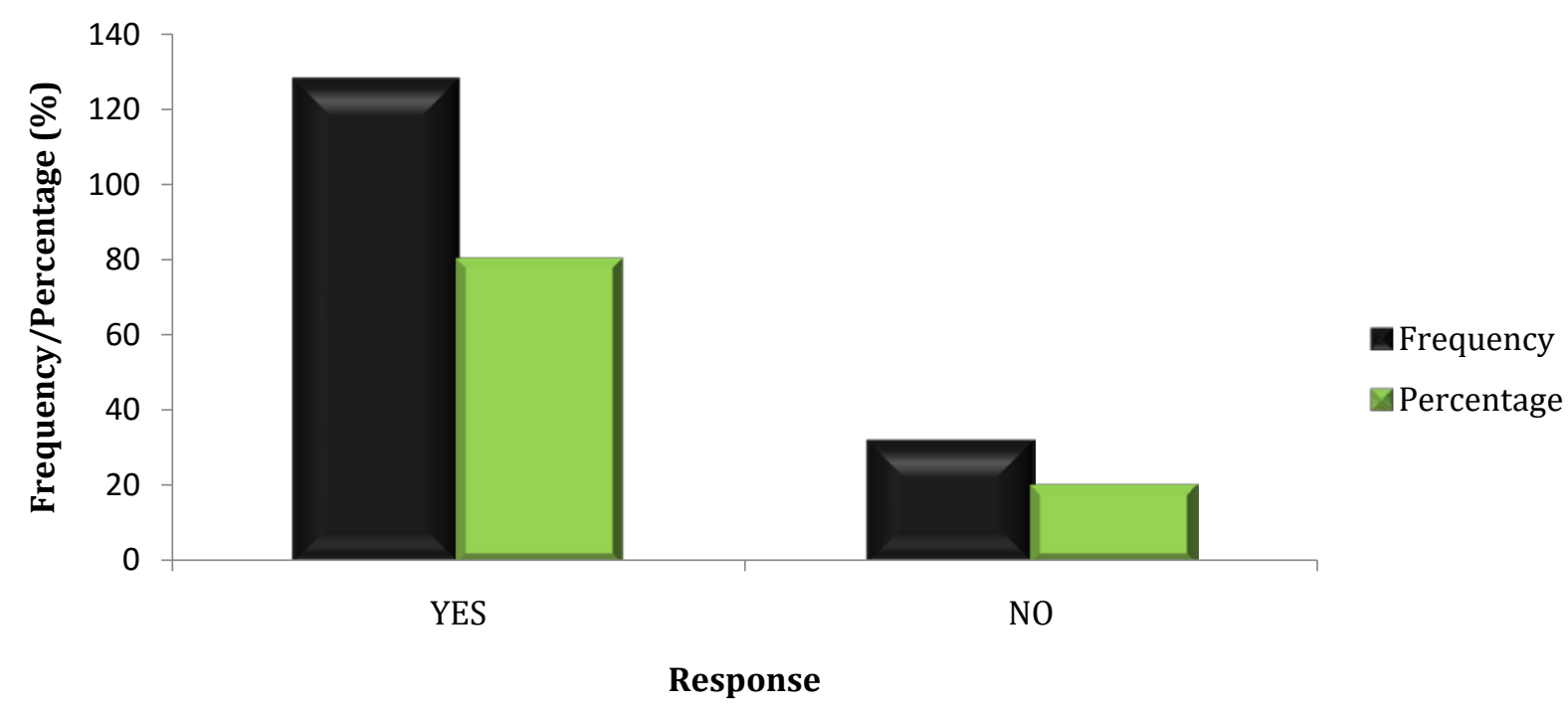

Figure 2

Change in Academic Performance of Students after Counseling Services

Figure 3 shows the distribution of class teacher's perception of the academic performance of students after counseling services. The majority of the class teachers (72\%) perceived the level of students' academic performance after counseling as good, while $20 \%$ of the class teachers perceived it very good and $8 \%$ rated it bad (Figure 3 ).

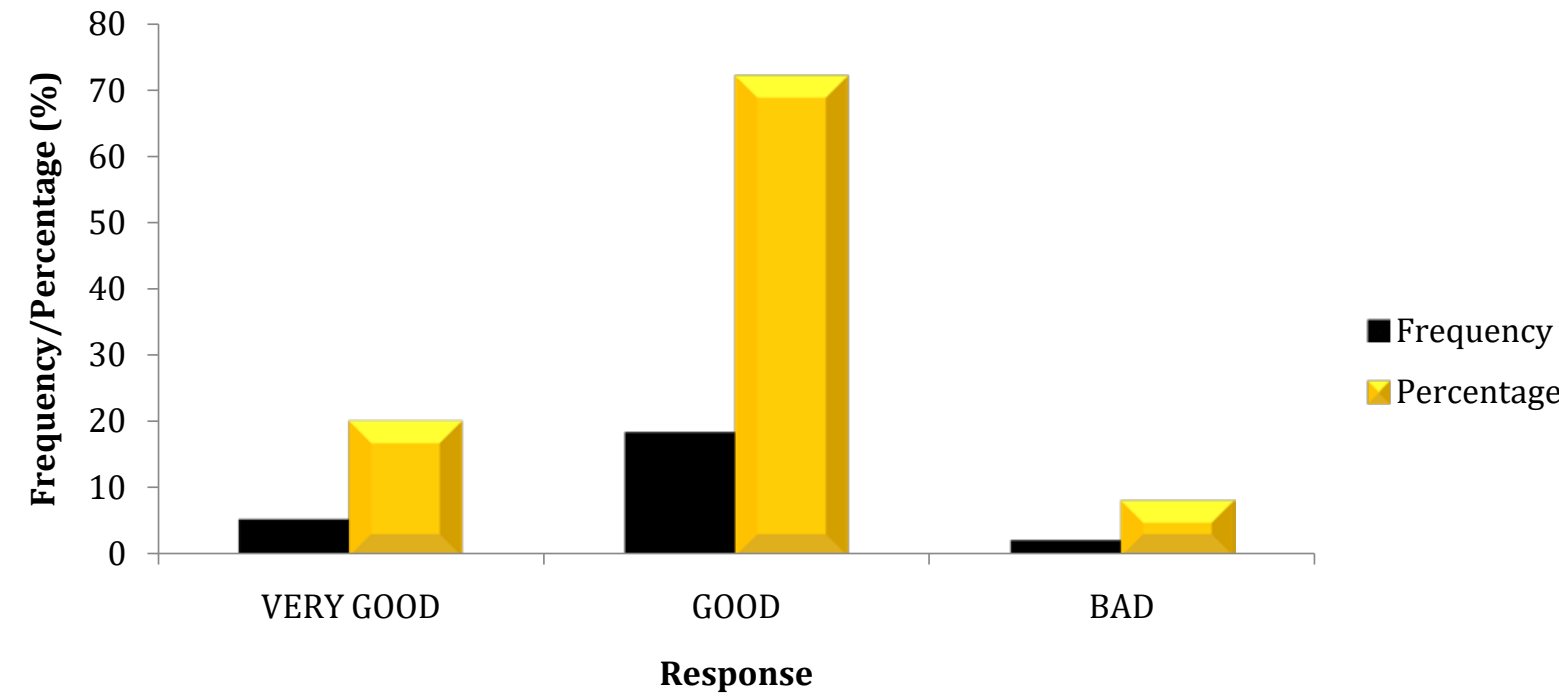

\section{Figure 3}

Class Teacher's Perception on Academic Performance of the Students after Counseling Services

The distribution of teacher counselors on the interest of students on guidance and counseling services is shown in figure 4 . The majority $(90 \%)$ of the teacher counselors responded that the students have no interest in the guidance and counseling services in the schools while the rest (10\%) responded that the students have on the services (Figure 4). 


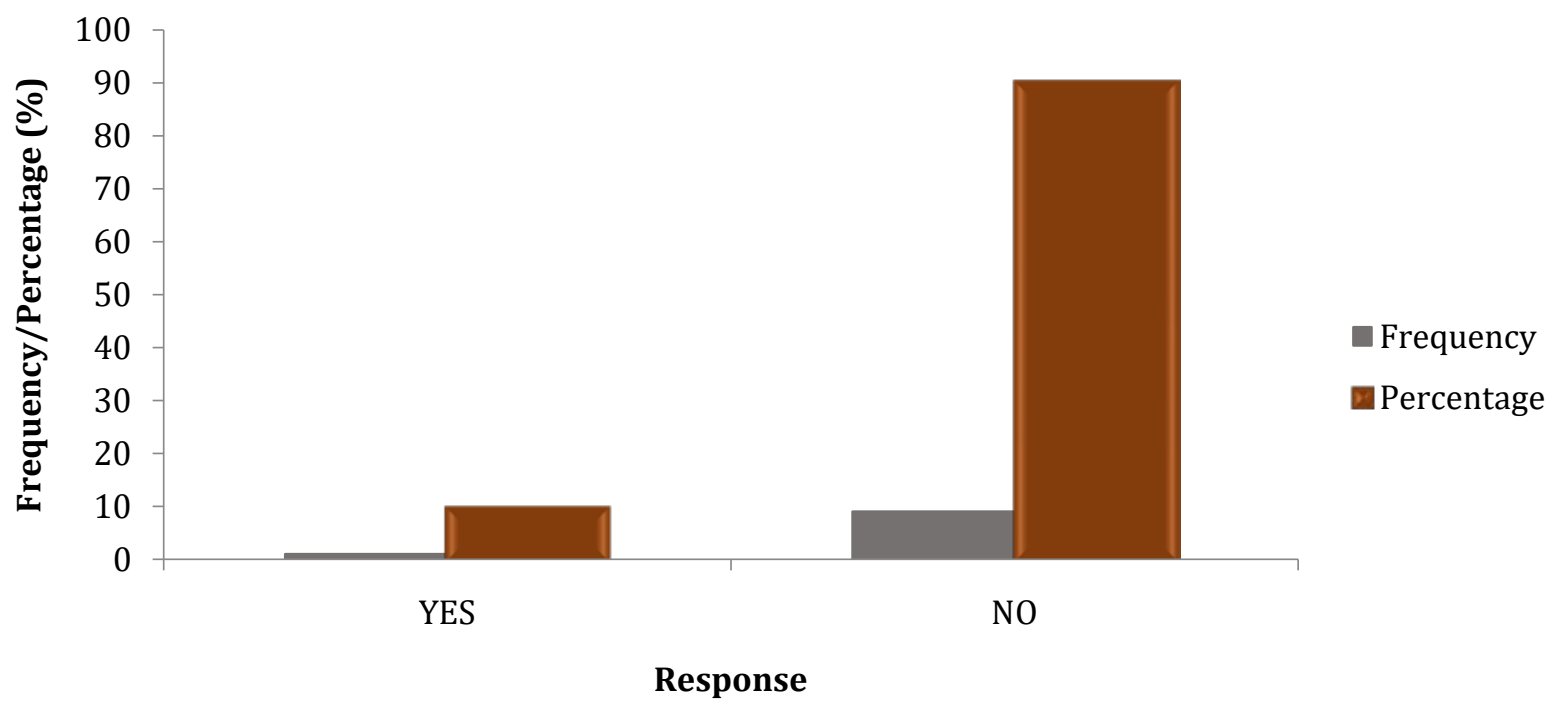

Figure 4

Interest of Students on Guidance and Counseling Services

Figure 5 shows the distribution of class teachers on attitudes of students toward guidance and counseling services. The majority (52\%) of the class teachers responded that the attitudes of students toward guidance and counseling services are encouraging while $40 \%$ responded very encouraging, 4\% responded discouraging and vary discouraging (Figure 5).

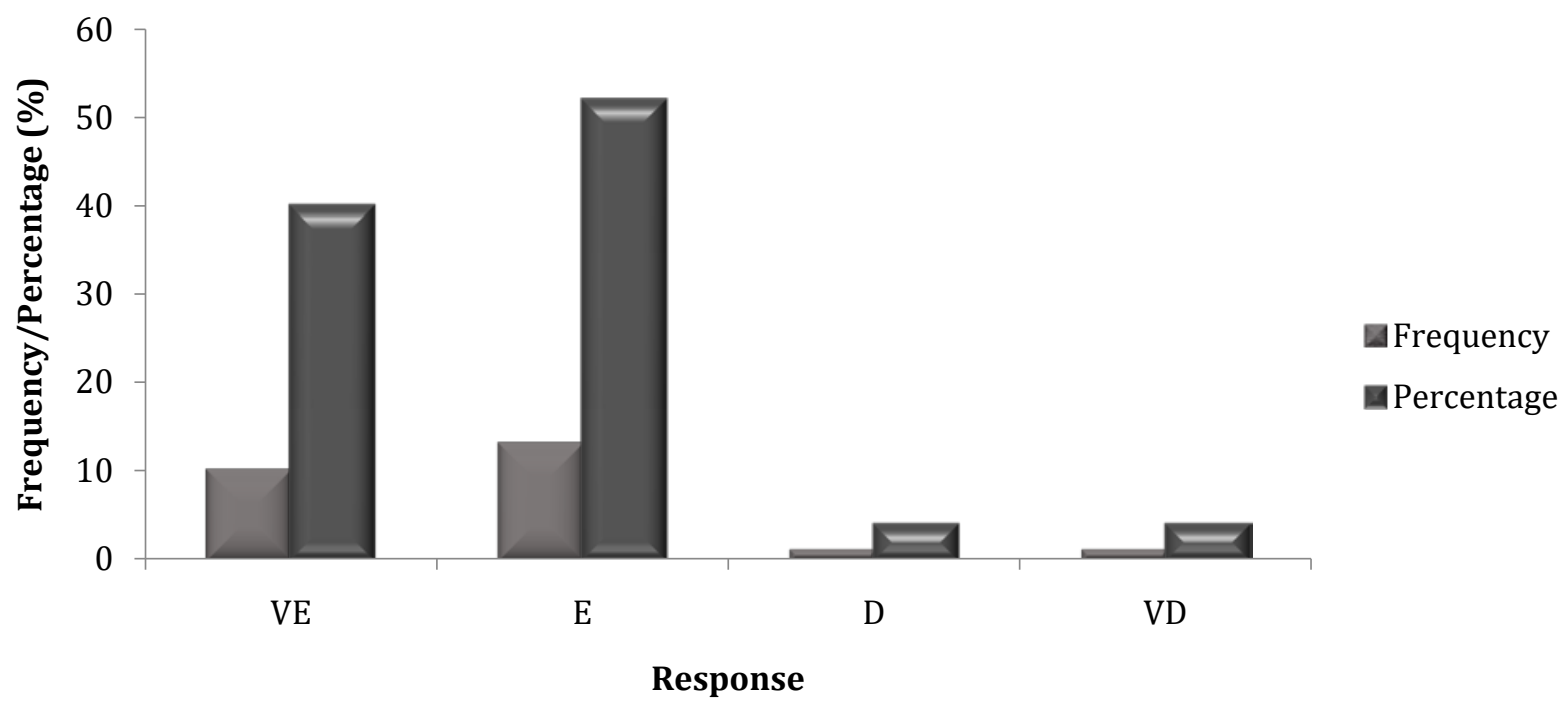

\section{Figure 5}

\section{Attitudes of Students toward Guidance and Counselling Services}

The distribution of class teachers by change of students' characters after counseling is shown in figure 6. Seventy-six percent (76\%) of the class teachers responded positively (yes) that students' characters change after counseling while the rest (24\%) responded negatively (no) that they have no observed any change in the students' characters after counseling (Figure 6). 


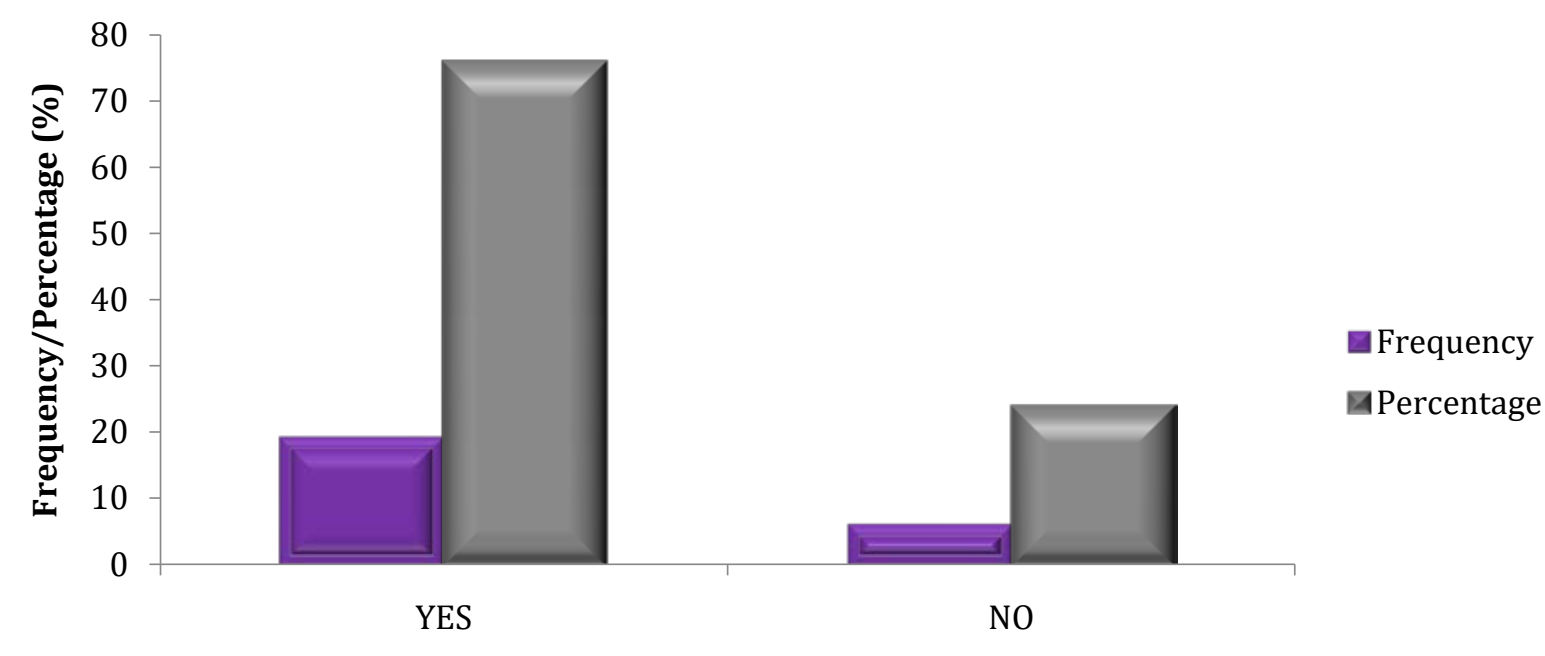

Response

\section{Figure 6}

\section{Change of Student's Character after Counselling}

\section{Discussion}

Education is the foundation for the development of any society and a teacher's qualification in teaching and learning is important in educational development. The National Policy on Education (NPE) Section 9, Sub-section 57 states that 'teachers' education will continue to be given major emphasis in all educational planning because no educational system can rise above the quality of its teachers" (NPE, 1998). In the present study, the majority of the respondents (principal, teacher counselors, and class teachers) are firstdegree holders. The National Policy on Education (1982) recommended a minimum of Nigeria Certificate in Education (NCE) for teaching in primary schools. It is, therefore, expected that a teacher with a first degree would teach at secondary schools and at least lecturers with master degrees would teach at tertiary institutions. The Counseling Association of Nigeria (CASSON) sets four criteria by which all counselors must adhere. The association requires guidance counselors to have at least a master's degree or higher or hold a professional certification in the expertise field.

The result of the current study indicated that the population of boys in the schools is more than that of the girls. The gender disparity could be attributed to the African cultural context that male education is prioritized over female education. In this study, it was found that students demonstrated good academic performance when counseling is done. The result of this study is in agreement with the study by Ngale (2009) which showed that students who received career guidance services demonstrated good academic performance compared to the students who had not. Also, a study by Ali (2014) showed a significant improvement in the academic performance of students who have received guidance and counseling services as compared to that of students who had not.

The result of the present study indicated that the provision of guidance and counseling services in the schools has made students developed positive attitudes or characters toward their school life. The result is in agreement with the report of Mwangi (2014) which states that guidance and counseling services result in a positive attitude towards good value and self-discipline. The result is also in agreement with the study by Ali (2002) which revealed that guidance and counseling is an important part of the educational process as it enables students to adjust better and fit in the school system. Also, Nweze and Okolie (2014) confirmed that guidance and counseling services improve students' academic performance 
and self-understanding and foster a positive attitude toward career choice. However, this study showed that most of the students cannot benefit from the services due to the lack of interest. This may have an impact on their performance, learning, and achievement and could be responsible for the poor performance of the students in the schools in national examinations.

\section{Conclusion}

The majority of the students demonstrated high academic performance after counseling services, hence guidance and counseling services have positively influenced the academic performance of the students. Therefore, it is recommended that teacher counselors should enhance the guidance and counseling programs in their schools to improve the academic performance of the students. Also, the government should add more support to the guidance and counseling program in the schools through the provision of funds for all the services in the program.

\section{References}

Ali, H. O. (2014). Career/vocational guidance/counselling: A tool for functional education and graduate employability. International Journal of Education and Practice. 2(10): 234242.

Chireshe and Mapfumo (2006). Guidance and counseling services enhanced students' academic performance, improve students' attitudinal determinants and reduce student dropout rates and prepare students for the world of work and life: A report.

Chireshe, R. and Mapfumo, J. (2006). School counsellors' perceptions of headmasters.

Corey, G. (2005). Theory and practice of counseling and psychotherapy ( $7^{\text {th }}$ ed.) Belmont: Brooke and Cole.

Davis, M. (2003). A book review: Brief counselling in schools: Working with young people from 11 to 18. By Denis Lines: Thousand Oaks, Califirnia: Stage Publications 2002; 210 pages: http://psychservices, in Psychiatryonline. 54(6): 917-918.

Ebizie, E. N., Enajedu, E. E. and Nkechi, E. (2016). The role of guidance and counselling in effective teaching and learning in schools. International Journal of Multidisciplinary Studies. 1(2): 36-48.

Egbochukwu, E. O. (2008). Guidance and counseling: A comprehensive text. Benin City. University of Benin Press.

Eremie, M. D. and Ibifari, B. (2018). Factors influencing students' career choice in secondary schools in Rivers state: Implication for Career Counselling. International Journal of Innovative Education Research. 6(4): 93-100.

Essuman, J. K. (2007). Guidance and counselling in basic and secondary schools in Ghana. Journal of Counselling, Education and Psychology. 1(2): 142-143.

Eyo, M. B., Joshua, A. M. and Esuong, A. E. (2010). Attitude of secondary school students towards guidance and counselling services in Cross River state. Edo Journal of Counsellng. 3(1): 87-99.

Mwangi, J. (2014). Influence of alternative disciplinary measures on students discipline in public secondary schools in Laikipia West District, Kenya. Unpublished M.Ed Thesis, University of Nairobi.

Ngale (2009). Gender alone does has any influence on the academic performance of students, but in combination with other factors can result into a challenging influence: A report. 
Ngale, I. F. (2009). Students, perception of school counseling government high schools in Bameda Subdivision, Cameroon. Education Community. http://www.thefreelibrary.com/_/print/PrintArticle.aspx?i d=1074006082

Nguyia, G. (2010). The role of guidance and counseling in schools in Makueni District. Unpublished M.Ed Thesis. University of Nairobi.

NPE (National Policy on Education) (2004). Federal Government of Nigeria. Federal Government Press, Lagos, Nigeria.

Nweze, T. and Okolie, U. (2014). Effective guidance and counseling programs in secondary schools: Issues and roles in students' career decision making. Journal of Research and Methods in Education. 4:63-68.

Okobiah, O. C. and Okorodudu, R. I. (2004). Concepts of guidance and counselling. In issues, concepts theories and techniques of guidance and counselling. Benin City: Ethiope Publishing Corp.

UNESCO (United Nations Educational, Scientific and Cultural Organization) (2006). EFA Global Monitoring Report 2006. Literacy for life. Paris.

Uwaifo, V. O. and Uddin, P. S. O. (2009). Transition from the 6-3-3-4 to the 9-3-4 system of education in Nigeria: An assessment of its implementation on technology subjects. Study Home Communication Science. 3(2): 81-86.

Zunker, V. G. (2002). Career counseling: Applied concepts of life planning (6 $6^{\text {th }}$ ed.) U.S.A: Brooks and Cole. 